\title{
EVALUATION OF HEPATOPROTECTIVE EFFECT OF ETHANOLIC EXTRACT FROM RED BETEL (PIPER CROCATUM RUIZ AND PAV.) LEAVES
}

\author{
LOURA NOVILIA*, URIP HARAHAP, POPPY ANJELISA ZAITUN HASIBUAN
}

Department of Pharmacology, Faculty of Pharmacy, University of Sumatera Utara, Medan, Indonesia. Email: lourapharma_001@yahoo.com Received: 28 February 2017, Revised and Accepted: 09 April 2018

\begin{abstract}
Objective: The objective of this study is to identify the effect of red betel (Piper crocatum Ruiz and Pav.) leaves ethanolic extract on hepatoprotective effect on $\mathrm{CCl}_{4}$-induced liver damage in rats.

Methods: Standard phytochemical screening method was done for preliminary phytochemical screening. Hepatotoxic rats were induced with $\mathrm{CCl}_{4}$ and treated with ethanolic extract of red betel leaves. The hepatoprotective test was divided into two groups (curative and preventive test). In the curative test, the rats which have been induced with $\mathrm{CCl}_{4}$ were given ethanol extract $600 \mathrm{mg} / \mathrm{kg}$ bw each day for 15 days. In the preventive test, the induced rats were given ethanol extract $600 \mathrm{mg} / \mathrm{kg}$ bw each day and $\mathrm{CCl}_{4}$ each $4 \mathrm{~h}$ for 45 days. Alanine aminotransferase (ALT), aspartate aminotransferase (AST), and alkaline phosphatase (ALP) parameters were also measured.
\end{abstract}

Result: The phytochemical screening showed an ethanolic extract of red betel leaves which contain a lot of phytochemical compounds. The result of hepatoprotective study showed that the ALT, AST, and ALP registered a significant $(\mathrm{p}<0.05)$ alteration in $\mathrm{CCl}_{4}$ treated rats.

Conclusion: The ethanolic extract of red betel leaves had the curative and preventive test.

Keywords: Red betel, Hepatotoxic, Hepatoprotective, $\mathrm{CCl}_{4}$.

(C) 2018 The Authors. Published by Innovare Academic Sciences Pvt Ltd. This is an open access article under the CC BY license (http://creativecommons. org/licenses/by/4. 0/) DOI: http://dx.doi.org/10.22159/ajpcr.2018.v11i7.25542

\section{INTRODUCTION}

The liver is one of the largest organs in the human body and performs many vital functions related to digestion, metabolism, immunity, and storage of nutrients within the body [1]. The liver as a vital organ in the body is primarily responsible for the metabolism of endogenous and exogenous agents. It plays an important role in drug elimination and detoxification, and liver damage may be caused by xenobiotics, alcohol consumption, malnutrition, infection, anemia, and medications [2].

Liver disease is a big problem in the health system, and the use of conventional medicine for the treatment of liver diseases is sometimes inadequate and causes serious side effects [3]. Based on the WHO (2004), the prevalence of liver cirrhosis is $1.3 \%$, and it is the $18^{\text {th }}$ leading cause of death with 800,000 cases. In the United States in 2009, chronic liver disease and cirrhosis were responsible for about 30,444 cases of deaths [4]. Hepatotoxicity is defined as injury to the liver that is associated with impaired liver function caused by exposure to a drug or another non-infectious agent [5]. Hepatotoxic agents can react with the basic cellular components and consequently induce almost all types of liver lesions.

Nature is always a golden sign to show the prominent phenomena of coexistence. Natural products from plants, animals, and minerals are the basis for treating human diseases [6,7]. One of the medicinal plants commonly used by people is red betel (Piper crocatum Ruiz and Pav.) plant. Betel plant has been known as an antiseptic since $600 \mathrm{BC}$. The types of betel generally used as medicine in Indonesia are green betel (Piper betel) and black betel. However, there is another type gaining popularity, i.e., red betel. Red betel is the type of betel often used as an ornamental plant in the 1990 s, but now it has shifted to medicinal function [8]. The present study investigates the hepatoprotective potential of red betel ethanolic extract treatment against $\mathrm{CCl}_{4}$-induced liver toxicity in rats.

\section{METHODS}

Collection of plant material

Fresh red betel leaves were collected in January 2016 from the local area of Berastagi and authenticated by Indonesian Institute of Sciences: Research Center for Biology. A voucher specimen was deposited in the Pharmacognosy Laboratory, Faculty of Pharmacy, University of Sumatera Utara.

\section{Plant extraction preparation}

Extraction was done by a maceration method. $900 \mathrm{~g}$ of powdered red betel leaves were macerated in advance with the solvent of ethanol for 5 days, then filtered, and do it continuously until the filtrate obtained is clear and colorless [9].

Phytochemical screening of various lotus leaf extract

Phytochemical screening carried out on various lotus leaf extracts which are hexane, ethyl acetate, and ethanol includes examing the secondary chemical metabolites of alkaloids, flavonoids, glycosides, saponins, tannins, triterpenoids, and steroids [10-12].

\section{Preparation of animals}

Healthy adult Wistar albino rats (150-200 g body weight) from animal house of the Faculty of Pharmacy, University of Sumatera Utara, were used for the study. Rats were housed in a polycarbonate cages in a room with $12 \mathrm{~h}$ day-night circle. They were fed on a standard pellet diet and water ad libitum. The study was approved by the Animal Research Ethics Committees (AREC) of University of Sumatera Utara, and the experiments were conducted according to the ethical norms and AREC guidelines (AREC registration number: 385/KEPH-FMIPA/2015). 


\section{Experimental design}

Curative hepatoprotective test

In the curative test, rats were divided into three groups. The first group served as baseline. Necrosis rats in the second group received Na CMC $0.5 \%$ suspension as a negative control. Group III necrosis rats were treated with ethanol extract of red betel at a dose of $600 \mathrm{mg} / \mathrm{kg} \mathrm{BW}$. Alanine aminotransferase (ALT), aspartate aminotransferase (AST), and Alkaline phosphatase (ALP) were observed on days 5, 10, and 15.

\section{Preventive hepatoprotective test}

Measurement of ALT, AST, and ALP before the treatment is the initial value. In the preventive test, rats were divided into three groups. Group I was healthy rats which were given $\mathrm{CCl}_{4}$ every 4 days with a dose of $1 \mathrm{ml} / \mathrm{kg}$ BW for 45 days as a control hepatotoxic. Group II is healthy rats which were given daily $\mathrm{Na}, \mathrm{CMC}$ and $\mathrm{CCl} 4$ every 4 days with a dose of $1 \mathrm{ml} / \mathrm{kg}$ BW for 45 days as a negative control. Group III is healthy rats which were given a daily dose of red betel ethanol extract at a dose of $600 \mathrm{mg} / \mathrm{kg}$ BW and CCl4 4 days with a dose of $1 \mathrm{ml} / \mathrm{kg}$ BW for 45 days. Rats' serum was taken for testing the activity of ALT, AST, and ALP on days 15,30 , and 45 .

\section{Statistical analysis}

All the data were expressed as mean \pm standard deviation. The significant difference of data between different groups was compared by ANOVA followed by Duncan's test.

\section{RESULTS}

\section{Phytochemical screening}

Screening results of various extract of lotus leaf extract showed different chemical compound in different extract (Table 1).

Table 1: Phytochemical screening result of red betel leaves ethanolic extract

\begin{tabular}{lll}
\hline No & Screening & Ethanol Extract \\
\hline 1 & Alkaloids & Positive \\
2 & Flavonoids & Positive \\
3 & Glycosides & Positive \\
4 & Saponins & Positive \\
5 & Tannins & Positive \\
6 & Triterpenoid/Steroids & Positive \\
\hline
\end{tabular}

Curative hepatoprotective test

In the curative test, the ethanolic extract was given after induction with $\mathrm{CCl}_{4} 1 \mathrm{ml} / \mathrm{kg} \mathrm{BW}$ every $4 \mathrm{~h}$ for 45 days. The measurement of the activity of ALT, AST, and ALP test can be seen in Table 2.

\section{Preventive hepatoprotective test}

In the preventive test, the ethanol extract of red betel dose of $600 \mathrm{mg} / \mathrm{kg}$ BW given every day and $\mathrm{CCl}_{4}$ was given then on the $4^{\text {th }}$ day $2 \mathrm{~h}$ before the extract. Results of preventive tests can be seen in Table 3.

\section{DISCUSSION}

The hepatoprotective activity may be attributed to classes of compounds present in it, such as flavonoids, alkaloids, and saponins [13]. Red betel contains flavonoids. Flavonoid compounds suspected of able to repair damaged liver cells. These compounds react to restore the damaged liver cells. The mechanism of hepatoprotective is by detoxifying toxic compounds, increasing the regeneration of liver cells, antiinflammatory and as an immunomodulator [14]. Flavonoids can control liver diseases [13]. As the anti-inflammatory agent, flavonoids can restore the permeability and increase the resistance of the capillary of blood vessels [15].

Based on Table 2, the activity of ALT, AST, and ALP in Group III with extract dose is $600 \mathrm{mg} / \mathrm{kg} \mathrm{BW}$ which did not differ significantly in the normal group ( $>0.05)$ and significantly different from the negative group $(\mathrm{p}<0.05) . \mathrm{CCl}_{4}$ may cause significant changes in serum liver enzymes [16]. This shows the effect of a decrease in ALT, AST, and ALP from the application of the extract. ALT is more accurate for liver function test than AST because ALT formed in the liver. Increased ALT enzymes in liver toxicity were caused by the loss of structural integrity of the liver [17].

Group III (dose $600 \mathrm{mg} / \mathrm{kgBW}$ ) showed a significant different with the negative control and the hepatotoxic control. Decreasing in liver serum level suggesting that the possibility of the extracts ability to protect the hepatocytes which caused by $\mathrm{CCl}_{4}$ [16]. This proves that extract may protect liver cells from damage caused by $\mathrm{CCl}_{4}$. Flavonoids are supposed to reduce theliver damage by binding free radicals so, the impact will be reduced. Free radicals will disrupt the membrane integrity of hepatocytes, thus removing various enzymes from hepatocytes, such as AST and ALT [18-20].

Table 2: Measurement ALT, AST, and ALP activity in the curative test

\begin{tabular}{|c|c|c|c|c|c|c|}
\hline Group & ALT & $\mathbf{p}$ & AST & $\mathbf{p}$ & ALP & $\mathbf{p}$ \\
\hline \multirow[t]{2}{*}{ Normal } & $102.515 \pm 5.336$ & $0.000^{\mathrm{b}}$ & $179.260 \pm 21.085$ & $0.000^{\mathrm{b}}$ & $28.500 \pm 30.505$ & $0.000^{\mathrm{b}}$ \\
\hline & & $0.059^{c}$ & & $0.073^{c}$ & & $0.825^{c}$ \\
\hline \multirow[t]{2}{*}{ Negative control } & $591.345 \pm 40.060$ & $0.000^{\mathrm{a}}$ & $727.340 \pm 110.064$ & $0.000^{\mathrm{a}}$ & $72.050 \pm 70.911$ & $0.000^{\mathrm{a}}$ \\
\hline & & $0.059^{c}$ & & $0.009^{c}$ & & $0.000^{c}$ \\
\hline \multirow[t]{2}{*}{ Extract control $(600 \mathrm{mg} / \mathrm{kg} \mathrm{BW})$} & $134.940 \pm 13.883$ & $0.000^{\mathrm{b}}$ & $337.450 \pm 57.835$ & $0.073^{\mathrm{a}}$ & $27.500 \pm 20.831$ & $0.825^{\mathrm{a}}$ \\
\hline & & $0.059^{\mathrm{b}}$ & & $0.009^{b}$ & & $0.000^{\mathrm{b}}$ \\
\hline
\end{tabular}

${ }^{a}$ The significant difference with the normal group, ${ }^{\mathrm{b} T h e}$ significant difference with the negative control group, ${ }^{\mathrm{C} T h e}$ significant difference with the normal group. ALT: Alanine aminotransferase, AST: Aspartate aminotransferase, ALP: Alkaline phosphatase

Table 3: Measurement of ALT, AST, and ALP in preventive test

\begin{tabular}{|c|c|c|c|c|c|c|}
\hline Group & ALT & $\mathbf{p}$ & AST & $\mathbf{p}$ & ALP & $\mathbf{p}$ \\
\hline \multirow[t]{2}{*}{ Hepatotoxic control } & $377.420 \pm 86.763$ & $0.263^{b}$ & $262.755 \pm 43.595$ & $0.057^{\mathrm{b}}$ & $49.350 \pm 90.585$ & $0.587^{\mathrm{b}}$ \\
\hline & & $0.003^{c}$ & & $0.003^{\mathrm{c}}$ & & $0.008^{\mathrm{c}}$ \\
\hline \multirow{4}{*}{$\begin{array}{l}\text { Negative } \\
\text { control } \\
\text { Extract control }(600 \mathrm{mg} / \mathrm{kg} \mathrm{BW})\end{array}$} & $470.040 \pm 96.161$ & $0.263^{\mathrm{a}}$ & $386.560 \pm 70.682$ & $0.057^{\mathrm{a}}$ & $38.300 \pm 60.387$ & $0.587^{\mathrm{a}}$ \\
\hline & & $0.012^{\mathrm{c}}$ & & $0.003^{c}$ & & $0.004^{c}$ \\
\hline & $179.695 \pm 22.778$ & $0.003^{\mathrm{a}}$ & $101.100 \pm 13.218$ & $0.003^{\mathrm{a}}$ & $18.850 \pm 20.378$ & $0.008^{\mathrm{a}}$ \\
\hline & & $0.012^{\mathrm{b}}$ & & $0.003^{\mathrm{b}}$ & & $0.004^{\mathrm{b}}$ \\
\hline
\end{tabular}

${ }^{a}$ The significant difference with the normal group, ${ }^{\mathrm{b}}$ The significant difference with the negative control group, ${ }^{\mathrm{c}}$ The significant difference with the normal group.

ALT: Alanine aminotransferase, AST: Aspartate aminotransferase, ALP: Alkaline phosphatase 


\section{CONCLUSIONS}

The result of this study demonstrates that red betel leaves ethanolic extract was effective for the curative and preventive of $\mathrm{CCl}_{4}$-induced hepatic damage in rats. However, the protective, curative, and preventive effect of red betel leaves needs to be confirmed by characterizing the active compounds of this plant as well as its mechanisms of action.

\section{ACKNOWLEDGMENTS}

The author would like to thank Iksen, B.Pharm., M.Sc. (Department of Pharmacy, STIKes Senior Medan) for his support and providing the research work and publication.

\section{CONFLICTS OF INTEREST}

The authors declared that there were no conflicts of interest.

\section{AUTHORS' CONTRIBUTION}

All the authors have contributed equally.

\section{REFERENCES}

1. Gideon MK, Omeh YN, Matthew IA. Hepatoprotective activity of methanolic extract of Jatropha tanjorensis in carbontetrachlorideinduced hepatotoxicity. Arch Appl Sci Res 2015;7:45-8

2. Mroueh M, Saab Y, Rizkallah R. Hepatoprotective activity of Centaurium erythraea on acetaminophen-induced hepatotoxicity in rats. Phytother Res 2004;18:431-3.

3. Zakaria ZA, Rofiee MS, Somchit MN, Zuraini A, Sulaiman MR, Teh LK, et al. Hepatoprotective activity of dried- and fermentedprocessed virgin coconut oil. Evid Based Complement Altern Med 2011;2011:1-8

4. Kochanek K, Deaths Preliminary Data for 2009. Natl Vital Stat Reports 2011;59:16

5. Gumaa SA, Hassan EM, Khalifa DM. Hepatoprotective effect of aqueous extracts of some medicinal plant mixtures on $\mathrm{CCl}_{4}$ induced liver toxicity. IOSE-J Pharm Biol Sci 2017;12:43-2, 52.
6. Kia FJ, Lorigooini Z, Khoei HA. Medicinal plants: Past history and future perspective. J Herbmed Pharmacol 2018;7:1-7.

7. Haro G, Sinaga SM, Iksen I, Nerdy N, Theerachetmongkol S. Protective effects of chives leaves (Allium schoenoprasum, L.) infusion against ethylene glycol and ammonium chloride induced nephrolithiasis in rats. J Appl Sci Pharm Sci 2017;7:222-5.

8. Sudewo B. Basmi Penyakit dengan Sirih Merah. Jakarta: Agromedia Pustake; 2005. p. 35-45.

9. Ditjen PO. Farmakope Indonesia. $4^{\text {th }}$ ed. Jakarta: Depkes RI; 1995. p. 896-8.

10. Depkes RI. Materia Medika. Vol. 6. Jakarta: Ditjen POM; 1995. p. 297-307.

11. Farnsworth NR. Biologycal and phytochemical screening of plants. J Pharm Sci 1996;55:225-76.

12. Harbone JB. Metode Fitokimia. Vol. 2. Bandung: ITB; 1987. p. 6, 49

13. Dalimarta S. Ramuan Tradisional untuk Pengobatan Hepatitis. Oleh: Penerbit Swadaya; 2001. p. 26-8

14. Balne D, Pallerla P, Vanapatla SR, Bobbala RK. Hepatoprotective effect of whole plant extract fractions of Marsilea minuta Linn. Asian J Pharm Clin Res 2013;6:100-7.

15. Fitriyani A, Winarti L, Muslichah S, Nuri N. Antiinflammatory test of red betel leaf methanol extract (Piper crocatum Ruiz \& Pav) in white rats. Traditional Herbal Magazine 2011;16:34-42.

16. Chellappann DK. Hepatoprotective effects of aqueous extract of Andrographis paniculata against $\mathrm{CCl} 4$ induced hepatotoxicity in albino wistar rats. Asian J Pharm Clin Res 2011;4:93-4.

17. Benayache S. Hepatoprotective effect of Genista quadriflora Munby extract against ethanol induced toxicity. Asian J Pharm Clin Res 2014; 7:226-9

18. Armansyah T, Sutriana A, Aliza D, Vanda H, Rahmi E. The hepatoprotective activity of ethanol extract of cat leaf (Acalypha indica L.) in white rats (Rattus novergicus) induced by paracetamol. J Ilmiah Ilmu Ilmu Peternakan 2010;8:292-8.

19. Rajalingam D, Varadharajan R, Palani S. Evaluation of Hepatoprotective and antioxidant effect of Combretu albidum $\mathrm{G}$ Don against $\mathrm{CCl}_{4}$ induced hepatotoxicity in rats. Int J Pharm Pharm Sci 2016;8:218-23.

20. Ingawale DK, Shah PV, Patel SS. Hepatoprotective effect of virgoliv syrup against $\mathrm{CCl}_{4}$ induced hepatic injury in rats. Int J Pharm Pharm Sci 2015; 7:221-6 